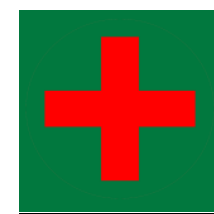

\title{
Tinjauan Penyimpanan Rekam Medis Di Ruang Filling Puskesmas Karang Mulya Kecamatan Bojongmangu Kabupaten Bekasi
}

\author{
Rifqi Fauzan ${ }^{1}$, Noor Yulia ${ }^{2}$, Laela Indawati ${ }^{3}$, Puteri Fannya ${ }^{4}$ \\ ${ }^{1}$ Program Studi Rekam Medis Dan Informasi Kesehatan, Universitas Esa Unggul, Jl. \\ Arjuna Utara No.9, Duri Kepa,Kebon Jeruk, Kota Jakarta Barat, DKI Jakarta. \\ Email: 1fauzan20180306028@ gmail.com, ${ }^{2}$ noor.yulia@esaunggul.ac.id, \\ ${ }^{3}$ laela.indawati@esaunggul.ac.id, ${ }^{4}$ puteri.fannya@esaunggul.ac.id
}

\begin{abstract}
The medical record storage system is very important to do in health care institutions, because it can make it easier for medical records to be stored in storage racks, speed up finding or retrieval and return, and protect medical records from theft, physical, chemical, and biological damage. The purpose of this study was to find out how the implementation of medical record storage in the filing room at Karang Mulya Health Center, Bojongmangu District, Bekasi Regency. The research method uses descriptive qualitative analysis method with the main informant being the head of the Puskesmas, other informants in charge of the medical record room, and medical record staff. The results of the study show that there is no standard operating procedure for storing medical records specifically for internal health centers, the results of the analysis of the storage space capacity can accommodate 30,000 medical records, and currently there are 16,319 medical records. The storage rack is still sufficient if there is a new medical record. The problem factor is in the filing room, the preparation of medical records is still stacked not in a row, and the medical records used are not immediately returned to the shelves, there has been no retention since 2017. Suggestions for standard operating procedures for storage procedures are made for internal health centers. Evaluate and improve the placement of medical records according to the applicable standards in the filing room.
\end{abstract}

Keywords: Storage Systems Medical Records, Filling Room

\begin{abstract}
Abstrak
Sistem penyimpanan rekam medis sangat penting untuk dilakukan dalam institusi pelayanan kesehatan, karena dapat mempermudah rekam medis yang akan disimpan dalam rak penyimpanan mempercepat ditemukannya atau pengambilan dan pengembaliannya, serta melindungi rekam medis dari bahaya pencurian, bahaya kerusakan fisik, kimiawi, dan biologi. Tujuan penelitian ini adalah untuk mengetahui bagaimana pelaksaan penyimpanan rekam medis di ruang filing di Puskesmas Karangmulya, Kecamatan Bojongmangu, Kabupaten Bekasi. Metode penelitian dengan menggunakan metode deskriptif analisis kualitatif dengan informan utama kepala Puskesmas, informan lain penanggung jawab ruang rekam medis, dan staff rekam medis. Hasil Penelitian menunjukan bahwa standar operasional prosedur tata cara
\end{abstract}


penyimpanan rekam medis belum ada yang khusus untuk internal Puskesmas, hasil analisa kapasitas ruang penyimpanan mampu menampung 30.000 rekam medis, dan rekam medis yang ada saat ini sebanyak 16.319 rekam medis. Rak penyimpanan masih cukup bila ada rekam medis baru. Faktor masalah di ruang filing, penyusunan rekam medis masih bertumpuk tidak berjajar, dan rekam medis yang dipakai tidak segera dikembalikan ke rak, belum ada retensi sejak tahun 2017. Saran standar operasional prosedur tata cara penyimpanan dibuat untuk internal Puskesmas. Lakukan evaluasi dan perbaikan pada penempatan rekam medis sesuai standar yang berlaku pada ruang filing.

Kata Kunci: Rekam Medis, Sitem Penyimpanan, Ruang Filling, Puskesmas.

\section{PENDAHULUAN}

Puskesmas adalah fasilitas pelayanan kesehatan yang menyelenggarakan upaya kesehatan masyarakat dan upaya kesehatan perseorangan tingkat pertama, dengan lebih mengutamakan upaya promotif dan preventif untuk mencapai derajat kesehatan masyarakat yang setinggi-tingginya di wilayah kerjanya. Puskesmas bekerja dibawah naungan Dinas Kesehatan Kabupaten/kota (Kemenkes, 2014)

Rekam medis adalah yang berisi catatan dan dokumen pasien yang terdiri dari identitas pasien, pemeriksaan, pengobatan, tindakan, dan pelayanan lain yang telah diberikan kepada pasien (Permenkes, 2008).

Sistem penyimpanan rekam medis sangat penting untuk dilakukan dalam institusi pelayanan kesehatan, karena sistem penyimpanan dapat mempermudah rekam medis yang akan disimpan dalam rak penyimpanan, mempercepat ditemukan kembali atau pengambilan rekam medis yang disimpan di rak penyimpanan, mudah pengembaliannya, dan melindungi rekam medis dari bahaya pencurian, bahaya kerusakan fisik, kimiawi, dan biologi (Hatta, 2014).

Menurut penelitian Ary Syahputra Wiguna dan Desy Risma Safitri pada tahun 2019 di RSU Sinar Husni disimpulkan bahwa Sistem penyimpanan rekam medis di RSU Sinar Husni menggunakan sistem sentralisasi. Sistem penjajaran di RSU Sinar Husni menggunakan dua angka akhir (terminal digit filling) dan masih ada rekam medis yang disimpan di dalam kardus dikarenakan kurangnya rak penyimpanan rekam medis (Wiguna, 2019).

Berdasarkan hasil observasi awal pada tanggal 24 November 2020, di ruang filling puskesmas terlihat rekam medis diletakan masih berantakan, masih adanya rekam medis yang tidak ditaruh di rak penyimpanan. Petugas terlihat membutuhkan waktu yang lama untuk mencari rekam medis pasien yang datang berobat dikarenakan posisi penyimpanan rekam medis bertumpuk.

Dari hasil wawancara kepada petugas di ruang filling dikatakan bahwa ruang penyimpanan terbatas hanya seluas $3 \times 4$ meter dengan jumlah rak penyimpanan sebanyak enam rak, dampak dari adanya permasalahan ini adalah terkadang petugas kesulitan untuk mencari rekam medis dikarenakan rekam medis diletakannya bertumpuk tidur tidak berdiri. 
Oleh sebab itu peneliti sangat tertarik mengambil judul tinjauan penyimpanan rekam medis di ruang filling Puskesmas Karang Mulya Kecamatan Bojongmangu Kabupaten Bekasi karena masalah yang terjadi dan sebaiknya ditata kembali sesuai dengan sistem tata laksana rekam medis yang berlaku agar memudahkan petugas dalam menjalani tugasnya sehari-hari.

\section{METODE}

Penelitian ini menggunakan metode penelitian analisis deskriptif bersifat kualitatif, peneliti melakukan penelitian dimulai dari bulan November 2020 sampai dengan bulan Juni 2021 dengan teknik observasi dan wawancara kepada petugas filling dan penanggung jawab ruang filling.

\section{HASIL}

Standar Operasional Prosedur Tata Cara Penyimpanan Rekam Medis di Puskesmas Karang Mulya Kabupaten Bekasi.

Dari observasi di puskesmas tanggal 15 Juni 2021, peneliti melakukan wawancara dengan informan utama disebutkan bahwa "SOP tata cara penyimpanan rekam medis mengacu pada BAB IV Permenkes Nomor 269 tahun 2008 tentang rekam medis yang berisi penyimpanan, pemusnahan, dan kerahasiaan."

Hasil wawancara kepada informan satu dikatakannya bahwa "Standar Operasional Prosedur di ruang filling Puskesmas Karang Mulya mengacu pada Peraturan Menteri Kesehatan Nomor 269 tahun 2008. Tidak ada standar khusus yang ditetapkan oleh Puskesmas."

Hasil wawancara dengan informan dua diperoleh informasi yang sama yaitu "Standar Operasional Prosedur di ruang filling Puskesmas Karang Mulya mengacu pada Peraturan Menteri Kesehatan Nomor 269 tahun 2008. Tidak ada standar khusus yang ditetapkan oleh Puskesmas.”

Mengukur Kapasitas Ruang Penyimpanan Rekam Puskesmas Karang Mulya Kabupaten Bekasi.

Setelah peneliti melakukan observasi di Puskesmas pada tanggal 15 Juni 2021, peneliti melihat bahwa ada enam rak penyimpanan, dengan ketebalan satu rekam medis sebesar 0,3 cm, dan peneliti akan mengukur kapasitas ruang penyimpanan berdasarkan rak penyimpanan yang ada. 
1. Mengukur rak penyimpanan rekam medis.

Tabel 1. Pengukuran Rak Penyimpanan

\begin{tabular}{llllllll}
\hline Rak & $\begin{array}{l}\text { Panjang } \\
(\mathrm{m})\end{array}$ & $\begin{array}{l}\text { Tinggi } \\
(\mathrm{m})\end{array}$ & $\begin{array}{l}\text { Lebar } \\
(\mathrm{m})\end{array}$ & $\begin{array}{l}\text { Sub } \\
\text { Rak }\end{array}$ & $\begin{array}{l}\text { Total Panjang Sub } \\
\text { Rak }(\mathrm{m})\end{array}$ & $\begin{array}{l}\text { Panjang } \\
\text { Rak }(\mathrm{cm})\end{array}$ & Sub \\
\hline Rak 1 & 3 & 2 & 0,4 & 6 & 18 & 1.800 \\
Rak 2 & 2 & 1,5 & 0,4 & 7 & 14 & 1.400 \\
Rak 3 & 2 & 1,5 & 0,4 & 8 & 16 & 1.600 \\
Rak 4 & 2 & 1,5 & 0,4 & 6 & 12 & 1.200 \\
Rak 5 & 2 & 1,5 & 0,4 & 9 & 18 & 1.800 \\
Rak 6 & 2 & 1,5 & 0,4 & 6 & 12 & 1.200 \\
Total & 13 & & & 42 & 90 & 9.000 & \\
\hline
\end{tabular}

\section{Jumlah penambahan rekam medis dalam lima tahun terakhir.}

Peneliti mengambil data kunjungan pasien selama lima tahun terakhir untuk jumlah rekam medis Puskesmas.

Tabel 2. data kunjungan pasien selama lima tahun terakhir

\begin{tabular}{llllll}
\hline Kunjungan & 2016 & 2017 & 2018 & 2019 & 2020 \\
\hline Total & 14,118 & 14,464 & 14,868 & 15,719 & 7,683 \\
\hline $\begin{array}{l}\text { Penambahan } \\
\text { Rekam } \\
\text { Medis }\end{array}$ & 346 & 404 & 851 & $-8,036$ \\
\hline
\end{tabular}

Setelah mengetahui data kujungan pasien selama lima tahun terakhir, peneliti menghitung jumlah pasien baru. Rata - rata penambahan rekam medis pertahun sangat bervariasi, namun pada tahun 2020 penambahan pasien baru tidak ada. Tahun 2020 adalah tahun pertama pandemi muncul di Indonesia, oleh sebab itu kunjungan pasien menurun drastis menyebabkan tidak adanya penambahan rekam medis pasien baru.

\section{Perhitungan ketebalan rata - rata rekam medis.}

Untuk mengetahui ketebalan rekam medis, peneliti mengambil 100 rekam medis terlebih dahulu kemudian diukur menggunakan penggaris. Didapat hasil sebesar $30 \mathrm{~cm}$, kemudian hasilnya pengukuran dibagi dengan 100 lalu dapat hasil sebesar 0,3 cm untuk satu berkas rekam medis.

\section{Kapasitas banyaknya rekam medis di rak penyimpanan.}

Setelah peneliti mengetahui rata-rata ketebalan rekam medis, peneliti ingin menghitung kapasitas banyaknya rekam medis menggunakan rumus sebagai berikut : 
$=\underline{\text { Total Panjang Sub Rak }}$, Berikut perhitungan kapasitas banyaknya rekam medis :

\begin{tabular}{lllllll}
\hline Rak & $\begin{array}{l}\text { Panjang } \\
(\mathrm{m})\end{array}$ & $\begin{array}{l}\text { Jumlah } \\
\text { Sub Rak }\end{array}$ & $\begin{array}{l}\text { Total } \\
\text { Panjang } \\
\text { Sub Rak } \\
(\mathrm{m})\end{array}$ & $\begin{array}{l}\text { Panjang } \\
\text { Sub Rak } \\
(\mathrm{cm}\end{array}$ & $\begin{array}{l}\text { Ketebalan } \\
\text { Rekam } \\
\text { Medis }\end{array}$ & $\begin{array}{l}\text { Kapasitas } \\
\text { Rekam } \\
\text { Medis }\end{array}$ \\
\hline Rak 1 & 3 & 6 & 18 & 1.800 & 0,3 & 6.000 \\
Rak 2 & 2 & 7 & 14 & 1.400 & 0,3 & 4.667 \\
Rak 3 & 2 & 8 & 16 & 1.600 & 0,3 & 5.333 \\
Rak 4 & 2 & 6 & 12 & 1.200 & 0,3 & 4.000 \\
Rak 5 & 2 & 9 & 18 & 1.800 & 0,3 & 6.000 \\
Rak 6 & 2 & 6 & 12 & 1.200 & 0,3 & 4.000 \\
Total & 13 & 42 & 90 & 9.000 & 0,3 & 30.000 \\
\hline
\end{tabular}

Setelah menghitung, peneliti dapat mengetahui banyaknya rekam medis disemua rak penyimpanan di ruang filling Puskesmas Karang Mulya Kabupaten Bekasi. Jumlah kapasitas rekam medis pada rak satu sebanyak 6.000 rekam medis, rak kedua sebanyak 4.667 rekam medis, rak ketiga sebanyak 5.333 rekam medis, rak keempat sebanyak 4.000 rekam medis, rak kelima sebanyak 6.000 rekam medis, dan rak keenam sebanyak 4.000 rekam medis. jika ditotal kapasitas pada rak penyimpanan sebanyak 30.000 rekam medis.

\section{Perbandingan antara kapasitas rekam medis di rak penyimpanan dengan jumlah rekam medis saat ini di ruang filling.}

Berdasarkan data jumlah rekam medis yang telah peneliti dapat serta menghitung jumlah kapasitas rekam medis pada rak penyimpanan. Jumlah rekam medis yang sudah ada sebanyak 66.852, dan jumlah kapasitas rak penyimpanan sebanyak 30.000 rekam medis. Berdasarkan data tersebut peneliti menyatakan rak penyimpanan sudah melebihi kapasitas, bahkan hingga dua kali lipat dari daya tampung yang bisa disimpan di rak penyimpanan.

\section{Faktor - Faktor Masalah Pada Penyimpanan Rekam Medis Di Puskesmas Karang Mulya Kabupaten Bekasi}

Setelah melakukan observasi peneliti menemukan masalah pada penyimpanan rekam medis seperti :

a. Dari pengamatan rekam medis yang telihat ada rekam medis yang tergeletak di lantai dan di dalam kotak, namun jika dilihat dari isi rak belum semuanya penuh. Menurut hasil wawancara kepada informan dua adalah "Iya ini (rekam medis) ditaruh di lantai sama di kotak karena sudah terlanjur, biar gampang aja gak bongkar - bongkar lagi rak yang lain”. Jadi masalah yang bisa terjadi adalah rekam medis bisa rusak jika ditaruh dilantai, bisa terkena tumpahan air atau bisa terinjak-injak oleh petugas jika sedang mengambil rekam medis lainnya.

b. Dari cara menyusun rekam medis dalam rak penyimpanan, penyusunannya masih bertumpuk tiduran, tidak berdiri maupun dimasukan kedalam box. Menurut hasil wawancara kepada informan dua adalah "rekam medis ditaruh secara bertumpuk itu biar gak jatuh kebawah, kan raknya bolong gak pake alas di subraknya, terus kita (Puskesmas) belum pengadaan box buat rekam medis 
jadinya ya ditaruh secara tiduran biar gak jatoh aja”. Masalah yang bisa terjadi adalah sulit untuk mengidentifikasi nomor rekam medis, tidak cepat untuk menemukan rekam medis karena harus diangkat satu persatu jika ingin mencari rekam medis yang dibutuhkan.

c. Dari sistem penomoran Puskesmas memakai penomoran unit numbering sistem. Unit numbering system adalah pemberian satu nomor rekam medis pada pasien yang datang ke Puskesmas, nomor yang diberikan akan dipakai selamanya untuk kunjungan berkelanjutan dan rekam medisnya tersimpan didalam satu berkas dengan nomor yang sama. Hasil wawancara dengan informan dua mengatakan "iya disini pake satu nomor rekam medis untuk satu pasien aja dan dipakai seterusnya". Masalah yang terjadi adalah bisa terjadi duplikasi nomor rekam medis.

d. Dari sistem penjajaran Puskesmas memakai penjajaran nomor langsung. Penjajaran nomor langsung adalah sistem penyimpanan dokumen rekam medis dengan mensejajarkan folder dokumen rekam medis berdasarkan urutan langsung nomor rekam medisnya dalam rak penyimpanan. Masalah yang bisa terjadi adalah jika subrak penuh akan membuat subrak yang baru.

e. Tidak adanya tracer/bon pinjam rekam medis. Bon pinjam rekam medis adalah sebuah tanda yang diberikan oleh petugas untuk rekam medis yang keluar dari rak penyimpanan. Dari hasil wawancara dengan informan dua mengatakan "puskesmas belum punya bon pinjam, masih pake tanda alakadarnya, ya dari kardus, ya dari sobekan kertas, yang penting bisa keliatan dulu deh". Kemudian masalah yang bisa terjadi adalah hilangnya rekam medis karena pencatatan rekam medis yang keluar tidak dilakukan. Selain itu rawan untuk salah simpan rekam medis karena bon pinjam tidak telihat begitu jelas.

\section{PEMBAHASAN}

Standar operasional prosedur yang digunakan Puskesmas untuk bagian rekam medis adalah Peraturan Menteri Kesehatan Nomor 269 Tahun 2008 tentang rekam medis. Tidak ada standar khusus yang dibuat oleh internal Puskesmas. Hal ini sejalan dengan penelitian Hasan pada tahun 2020 di RSUP Dr. Sardjito bahwa hasil dari unsur method yaitu standar prosedur operasional tentang pelaksanaan pemeliharaan dokuman rekam medis masih belum tersedia (Hasan et al., 2020).

Hasil dari perhitungan adalah kapasitas ruang penyimpanan rekam medis sebanyak 30.000 rekam medis, rekam medis yang ada saat ini sebanyak 16.319 rekam medis. Ternyata kapasitas rak masih memadai, masih cukup jika ada tambahan rekam medis baru sebanyak 13.681 rekam medis. Hal ini sejalan dengan penelitian Esraida Simanjuntak dan Rizka Mei Shella di Rumah Sakit DR. Pirngadi Medan pada tahun 2019 bahwa Pelaksanaan pemeliharaan dokumen rekam medis masih belum memadai karena rak penyimpanan yang masih menggunakan kayu sehingga menyebabkan mudahnya terserang rayap, rak yang masih kurang sehingga menyebabkan dokumen rekam medis ada yang diletakkan di bawah lantai. Dari aspek fisik belum memadai, karena masih adanya folder atau dokumen rekam medis yang belum diberi sampul dan 
belum mengganti folder yang rusak dengan yang baru. Suhu dan kelembapan ruangan yang kurang dan belum memenuhi standar teori yang ada (Simanjuntak \& Shella, 2019).

Hasil penelitian rekam medis yang telihat di ruang Filing ada yang tergeletak di lantai, tidak masuk ke dalam sub rak penyimpanan, ada juga rekam medis yang ditaruh di box yang disimpan diatas rak, hal ini terjadi karena kurangnya rak penyimpanan yang memadai. Jika dilihat secara langsung rak penyimpanan belum begitu penuh. Penyusunan rekam medis di Puskesmas Karang Mulya secara bertumpuk dengan posisi rekam medis tidur, tidak berdiri meyamping karena tidak adanya box untuk menyimpan rekam medis secara berdiri. Hal ini sejalan dengan penelitian dari Ary Saputra Wiguna dan Desy Risma Safitri pada tahun 2009 di RSU Sinar Husni menyatakan bahwa masih ada rekam medis yang disimpan di dalam kardus dikarenakan kurangnya rak penyimpanan rekam medis (Wiguna, 2019).

\section{KESIMPULAN DAN SARAN}

Standar operasional prosedur tata cara penyimpanan rekam medis belum ada yang khusus internal Puskesmas, Standar operasional yang digunakan oleh unit rekam medis adalah standar operasional yang umum. Hasil analisis kapasitas ruang penyimpanan masih mampu menampung 30.000 rekam medis, dan rekam medis yang ada saat ini ada sebanyak 16.319 rekam medis. Rak penyimpanan masih cukup bila ada rekam medis yang baru. Faktor masalah di ruang filing penyusunan atau penataan rekam medis bertumpuk tidak berjajar tidak adanya tracer dan rekam medis yang dipakai tidak segera dikembalikan ke rak, belum ada retensi sejak tahun 2017.

\section{DAFTAR PUSTAKA}

Hasan, M., Farlinda, S., Erawantini, F., \& Wicaksono, A. P. (2020). Tinjauan Pelaksanaan Pemeliharaan Dokumen Rekam Medis Di Ruang Filling RSUP Dr. Sardjito. 1(4), 639-650.

Hatta, G. (2014). Pedoman Manajemen Informasi Kesehatan disarana pelayanan kesehatan (G. R. Hatta (ed.); revisi 3). penerbit universitas indonesia.

Kemenkes. (2014). Peraturan Menteri Kesehatan Nomor 75 Tahun 2014 Tentang Puskesmas. Lincolin Arsyad, 3(2), 1-46. http://journal.stainkudus.ac.id/index.php/equilibrium/article/view/1268/1127

Permenkes. (2008). Peraturan Menteri Kesehatan Nomor 269 Tahun 2008 Tentang Rekam Medis. In Permenkes Ri No 269/Menkes/Per/Iii/2008 (Vol. 2008, p. 7).

Simanjuntak, E., \& Shella, R. M. (2019). Tinjauan Pelaksanaan Pemeliharaan Dokumen Rekam Medis di Ruangan Filling Rumah Sakit DR. Pirngadi Medan Tahun 2019. Jurnal Ilmiah Perekam Dan Informasi Kesehatan Imelda, 5(2), 114120.

Wiguna, S. (2019). Tinjauan Sistem Penyimpanan Dokumen Rekam Medis Di RSU Sinar Husni Tahun 2019. Jurnal Ilmiah Perekam Medis Dan Informasi Kesehatan Imelda, 4(2), 648-654. 